\title{
Synthesis of polymer-grafted gold nanoparticles via gamma radiation*)
}

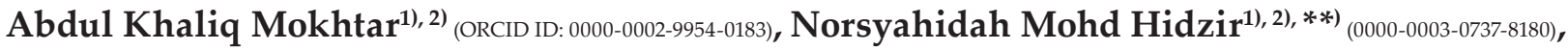

 \\ Nur Ain Mohd Radzali1), 2)
}

DOI: dx.doi.org/10.14314/polimery.2021.11.3

\begin{abstract}
The research focused on the synthesis of polytetrafluoroethylene (PTFE) grafted with gold nanoparticles (AuNP). The Turkevich method, one of the common techniques of AuNP synthesis, was used to obtain an AuNP solution with a nanoparticle size of $20 \mathrm{~nm}$. The PTFE-AuNP samples were subsequently irradiated and the absorbed doses were 0.5, 2, 5, 10 and $20 \mathrm{kGy}$. It was noticed that samples irradiated with 0.5 and $2 \mathrm{kGy}$ were less stable and less concentrated than samples irradiated with higher doses due to aggregation and formation of precipitation after 30 days.
\end{abstract}

Keywords: gold nanoparticles, polymer, grafting, radiosensitizers.

\section{Synteza polimerów szczepionych nanocząstkami złota z wykorzystaniem promieniowania gamma}

Streszczenie: W artykule omówiono technikę syntezy poli(tetrafluoroetylenu) (PTFE) szczepionego nanocząstkami złota (AuNP). Metodą Turkevicha, jedną z powszechnie stosowanych technik syntezy AuNP, uzyskano roztwór AuNP o wielkości cząstek 20 nm. Próbki roztworu PTFE-AuNP były następnie naświetlane promieniowaniem gamma; zaabsorbowane dawki promieniowania wyniosły 0,5, 2, 5, 10 oraz 20 kGy. Stwierdzono, że w przypadku dawek 0,5 i 2 kGy roztwór był mniej stabilny, a stężenie nanocząstek było niższe niż w przypadku wyższych dawek. Wiązało się to z agregacją i precypitacją nanocząstek po upływie 30 dni od naświetlania.

Słowa kluczowe: nanocząstki złota, polimer, szczepienie, radiouczulacze.

Gold has generally been a precious metal since the beginning of human civilization and is versatile in every aspect of daily life from currency and jewellery to industry as well as medicine. Gold nanoparticles (AuNP) are one of the materials that provide benefits in the engineering of nanomaterials for radiotherapy, diagnostics, and even theranostics due to their shape and size-dependent properties [1], strong surface Plasmon resonance properties [2, 3], and excellent biocompatibility [4].

Various approaches can be used to produce gold nanoparticles such as the Turkevich method [5], Brust-Schiffrin [6], seed-mediated growth [7] and others with

1) Department of Applied Physics, Faculty of Science and Technology, Universiti Kebangsaan Malaysia, 43600 Bangi, Selangor, Malaysia.

2) Nuclear Technology Research Centre, Faculty of Science and Technology, Universiti Kebangsaan Malaysia, 43600 Bangi, Selangor, Malaysia.

*) Material contained in this article was presented at the $1^{\text {st }} \mathrm{Ma}$ laysia International Conference on Nanotechnology \& Catalysis (MICNC 2021), 1-3 September 2021, Malaya, Malaysia.

**) Author for correspondence: syahidah@ukm.edu.my each having its advantages and disadvantages. The Turkevich method was chosen for this study because it can produce spherical AuNPs of size $10 \mathrm{~nm}$ up to $30 \mathrm{~nm}$ and its monodispersity is in a satisfactory range. Another advantage of this method is that the citrate ions take on a double role, acting as a reducing agent and a stabilizing agent [8]. This method can also be used to produce AuNP with a size of more than $30 \mathrm{~nm}$ but the polydispersity of the AuNP solution will be higher and the quality of its spherical shape will also be affected [9].

Monodisperse AuNP solution can provide clearer diagnostic results [10] and precise delivery of ionizing radiation in radiotherapy [11] compared to polydisperse AuNP solution. To exploit these advantages, this study takes the approach through centrifugation method to produce a monodisperse AuNP solution. There are various ways to separate AuNP solutions according to size such as size exclusion chromatography [12] and gel electrophoresis [13]. However, each of these methods is time consuming and requires secondary chemical modifications to the nanoparticles.

Polymer grafted AuNP as radiosensitizing agent has a great potential in the scientific community and medi- 
cal sector. The booming of research and study related to AuNP in recent years could lead to its usage in medical practice in just around the corner. The type of polymers and way to synthesize them together with grafting to or from AuNP are limitless and each and every one of them has unique characteristics and benefit that could be reaped for more precise and targeted radiotherapy. Polymer-grafted gold nanoparticles improve the issue of AuNP in biological media by ensuring good dispersibility and long-term stability [14].

When the size of particle decreases, the wavelength of SPR related absorption shifts to shorter, bluer wavelength (blueshift) and vice versa [15]. By altering the form or size of the AuNP, the SPR could be controlled, resulting in particles with specific optical properties for various applications [16]. Based on this phenomenon, the wavelength of a particular AuNP solution could determine the approximate size of AuNP particles inside it [9].

\section{EXPERIMENTAL PART}

\section{Materials}

All flasks were washed with aqua regia solution before use to clean them out of contaminants such as precious metal substrates [17]. Aqua regia was produced by mixing hydrochloric acid and concentrated nitric acid (both obtained from Sigma-Aldrich) with a volume ratio of 3:1. The materials used to synthesize gold nanoparticles were chloroauric acid $\left(\mathrm{HAuCl}_{4}\right)(99.995 \%$ trace metal basis) and dehydrated trisodium citrate $\left(\mathrm{Na}_{3} \mathrm{Ct}\right)$, both obtained from Sigma-Aldrich. Deionized water was also used in each procedure. All materials listed were used directly without additional purification.

\section{AuNP synthesis}

In synthesizing of gold nanoparticles (AuNP), $100 \mathrm{ml}$ of $0.5 \mathrm{mM} \mathrm{HAuCl}_{4}$ solution in a volumetric flask and $1.0 \mathrm{wt} \%$ of $\mathrm{Na}_{3} \mathrm{Ct}$ solution were prepared. The flask containing $\mathrm{HAuCl}_{4}$ solution was heated continuously by a heating plate and stirred rapidly with a magnetic stirrer. When the $\mathrm{HAuCl}_{4}$ solution reached its boiling point $\left(100^{\circ} \mathrm{C}\right), 4.13 \mathrm{ml}$ of $\mathrm{Na}_{3} \mathrm{Ct}$ solution was rapidly injected into the $\mathrm{HAuCl}_{4}$ solution [9]. AuNP synthesis was completed when there were no changes of suspension's color. This particular reaction could take 2 to 5 minutes, depending on the molar ratio (MR). Finally, the samples were allowed to cool down to room temperature.

\section{PTFE-AuNP synthesis}

The PTFE solution was added to AuNP solution in molar ratio of 10:1 (PTFE:AuNP) and after that was bubbled with nitrogen for 15 minutes to remove possible dissolved gases. Gammacell 220 from Nordion, a fully self-contained research irradiator that provides high-intensity gamma radiation, was used to irradiate the PTFE-AuNP samples with doses 0.5, 2, 5, 10 and $20 \mathrm{kGy} .2 \mathrm{ml}$ of each irradiated sample was centrifuged at 7,000 g-force for 30 minutes using Eppendorf F-45-12-11 [18]. The centrifugation process increased the concentration of PTFE-AuNP and the PTFE-AuNP pellets were thereafter redispersed to receive washed PTFE-AuNP solution.

The optical properties of AuNP were examined via ultraviolet-visible (UV-Vis) spectrometry using Lambda 35 from Perkin Elmer after being left on shelf for 30 days. Samples were prepared in a U-shaped bottom ultraviolet (UV) quartz cuvette by diluting $1 \mathrm{ml}$ of PTFE-AuNP solu- a)

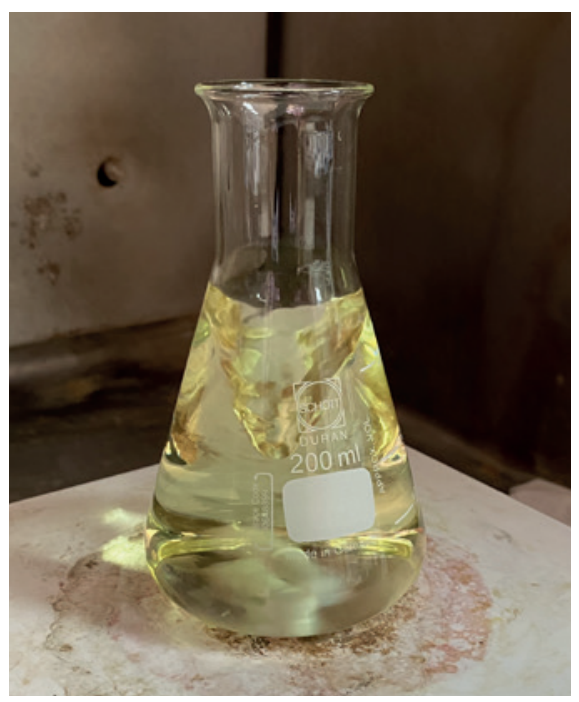

b)

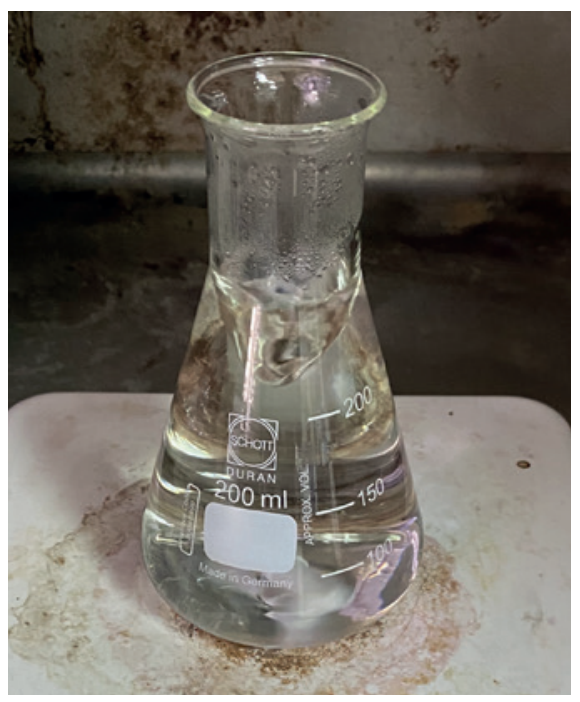

c)

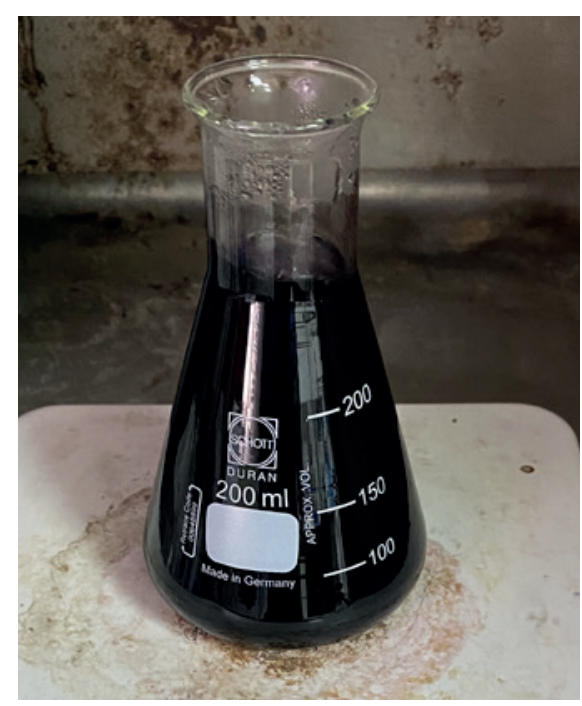

Fig. 1. The changes of $\mathrm{HAuCl}_{4}$ solution color: a) yellow (before AuNP synthesis reaction took place), b) clear solution (first stage of AuNP synthesis), c) deep purple (after fourth stage of AuNP synthesis) 


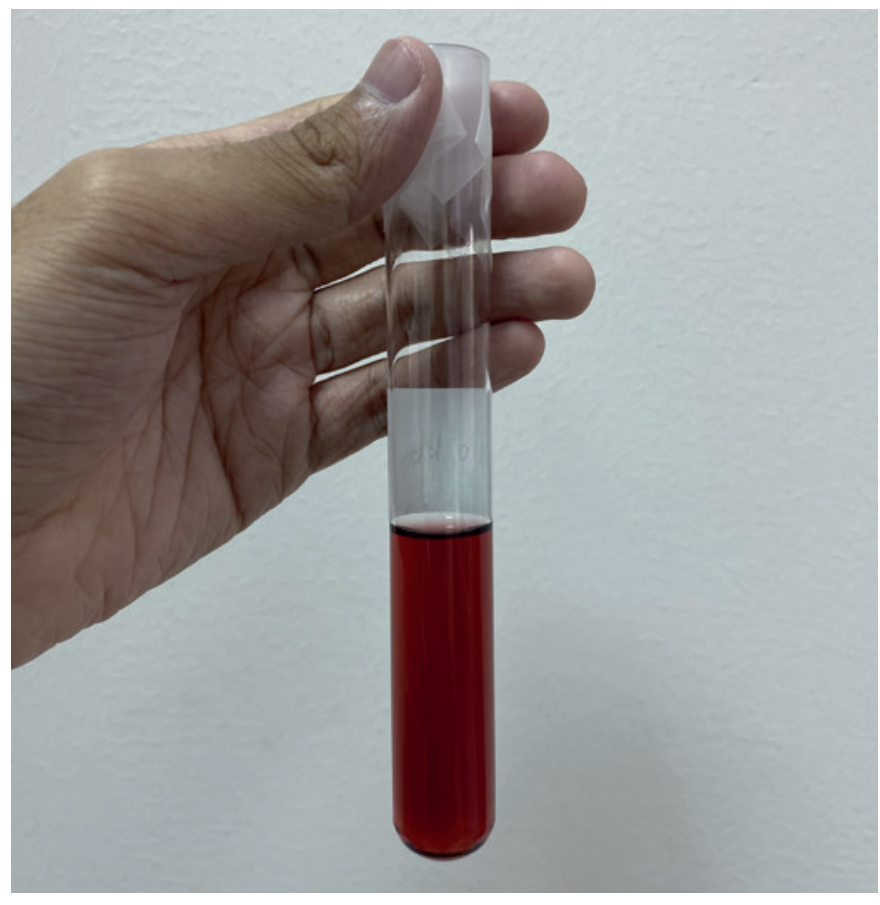

Fig. 2. Final red wine color of washed PTFE-AuNP solution

tion with $3 \mathrm{ml}$ of ionized water. The wavelength used in measurements was 300 to $800 \mathrm{~nm}$.

\section{RESULTS AND DISCUSSION}

\section{Color changes in synthesized AuNP}

According to the recent study by Polte et al. [19], the reason of color changes during synthesis of AuNP solution are the three phases of AuNP synthesis, from rapid nucleation through random attachment to intraparticle ripening observed under various reaction circumstances.

a)

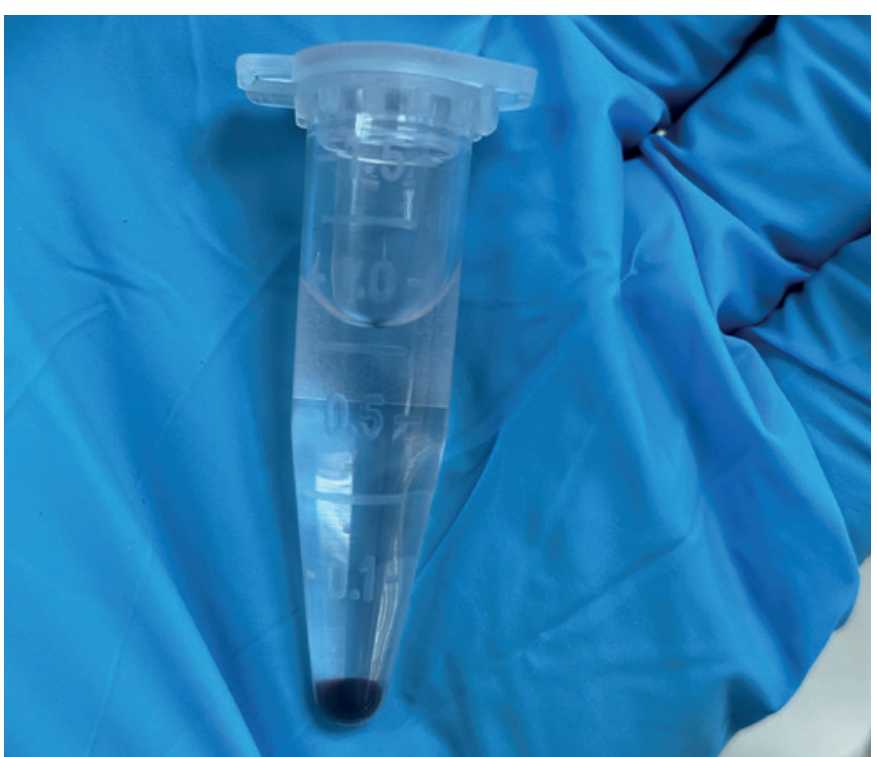

These three phases of AuNP could be demonstrated as a four-step nucleation and growth process, with the initial phase splitted into two steps [19]. The initial color of $\mathrm{HAuCl}_{4}$ solution was yellow due to no reaction taking place (Fig. 1a). After addition $\mathrm{Na}_{3} \mathrm{Ct}$ into $\mathrm{HAuCl}_{4}$ solution, the transition from yellow to clear solution was observed (Fig. 1b) and could be explained by a rapid production of small nuclei (first stage) and afterwards either the nuclei coalescing [9] or Ostwald ripening [20] into larger particles (second stage). At the third stage, additional coalescence and continuous gold precursor reduction promoted the particles' slow growth of diffusion. In the last stage, the color of AuNP solution turned into deep purple (Fig. 1c), and later into red wine color (Fig. 2), when the particles grew rapidly reaching their final size, as a result of complete consumption of the precursor species [21].

On the way of centrifugation process it was possible to extract PTFE-AuNP pellet (Fig. 3a) and isolate them from contaminants in the supernatant obtained in the PTFE-AuNP solution. Similar observations are described by S.K. Balasubramanian et al. [18], who separated AuNP colloids in form of pellets and purified from non-AuNP components (supernatant) using two rounds of centrifugation of $1 \mathrm{ml}$ of freshly synthesized AuNP solution at different centrifugation forces [18]. The washed solution of PTFE-AuNP (Fig. 3b) was obtained by redispersion of PTFE-AuNP pellets in ionized water of its original volume.

\section{Ultraviolet-visible spectrophotometry (UV-Vis)}

In Figure 4, the results of researches on optical absorbance of PTFE-AuNP solution using ultraviolet-visible spectrophotometry (UV-Vis) are presented. At $520 \mathrm{~nm}$ a peak was observed, which suggested that the size of

b)

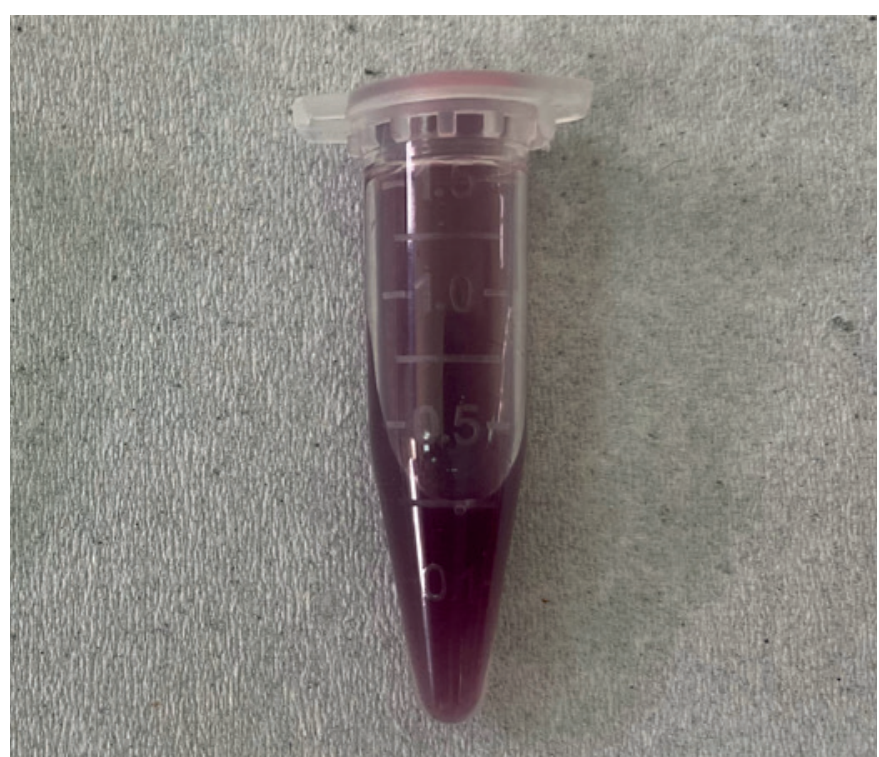

Fig. 3. Isolated PTFE-AuNP pellets (a) and washed PTFE-AuNP solution after redispersion of pellets in water (b) 


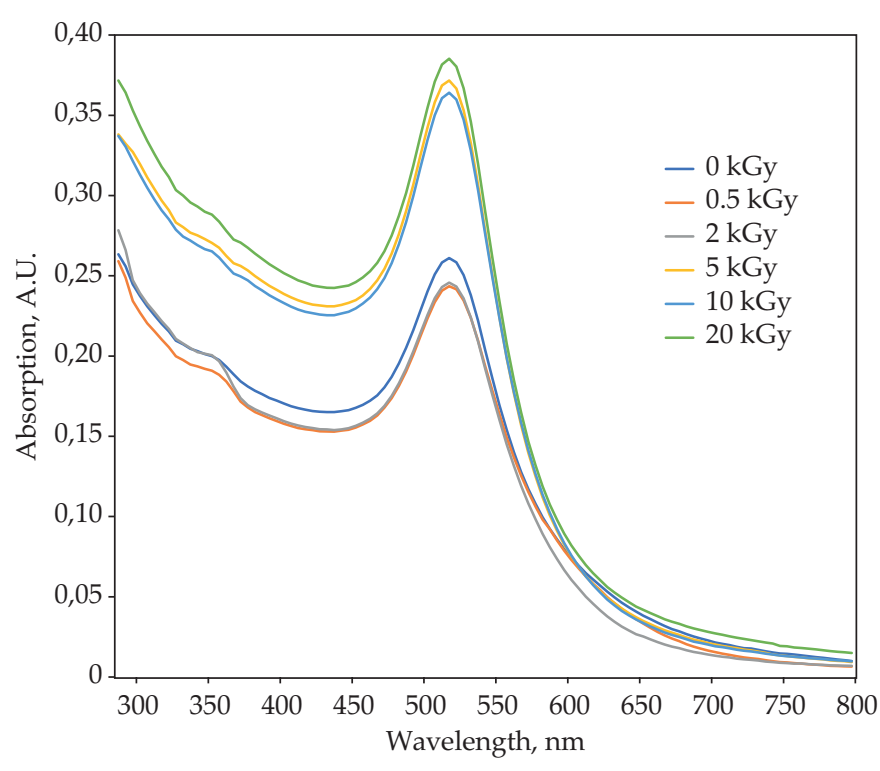

Fig. 4. Optical absorbance of PTFE-AuNP samples irradiated with various doses, the difference in curves between low and high doses could be observed the obtained PTFE-AuNP particles was approximately $20 \mathrm{~nm}$. The similar findings were done by Li et al., who obtained size of particles AuNP equal $20 \mathrm{~nm}$ using TEM analysis and noticed $520 \mathrm{~nm}$ band in UV-Vis [22]. In addition, Xing et al. synthesized graphene oxide/AuNP composite $(\mathrm{GO} / \mathrm{AuNP})$ and reported the absorption peak at $520 \mathrm{~nm}$ (UV-Vis) for $20 \mathrm{AuNP}$ as well [23].

Current study showed the difference in optical absorbance of PTFE-AuNP samples irradiated with 0.5 and 2 kGy dose (Fig. 4) compared to other doses. The difference in curves could be explained by aggregation of PTFE-AuNP which occurred at lower doses (0.5 and $2 \mathrm{kGy}$ ) and was verified by visible precipitation in samples irradiated with 2 kGy (Figs. 5b and 5c). The irradiation doses were found not to have a significant influence on the size of PTFE-AuNP obtained in this study. The absorption peak was found to retain at $520 \mathrm{~nm}$ regardless the doses used (Fig. 4). Non-irradiated AuNP were well diffused, despite some aggregation (Fig. 5a), while no aggregation was visible in PTFE-AuNP samples irradiated with 5, 10 and 20 kGy (Figs. 5d, 5e and 5f). Le Goas et al. noticed that irradiated with 4 and $20 \mathrm{kGy}$ of gamma radiation poly(methacrylic acid)-grafted AuNP (PMAA-AuNP) and poly(2-hydroxyethylmethacrylate-meth- a)

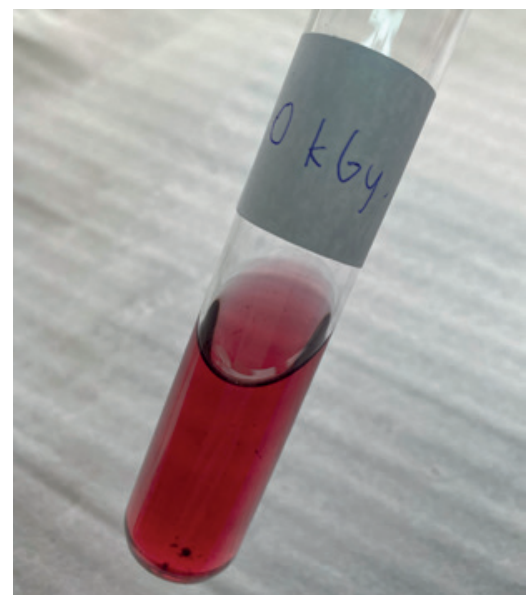

d)

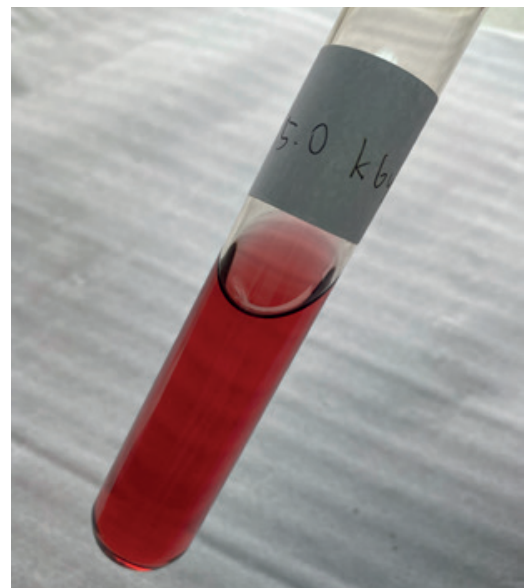

b)



e)

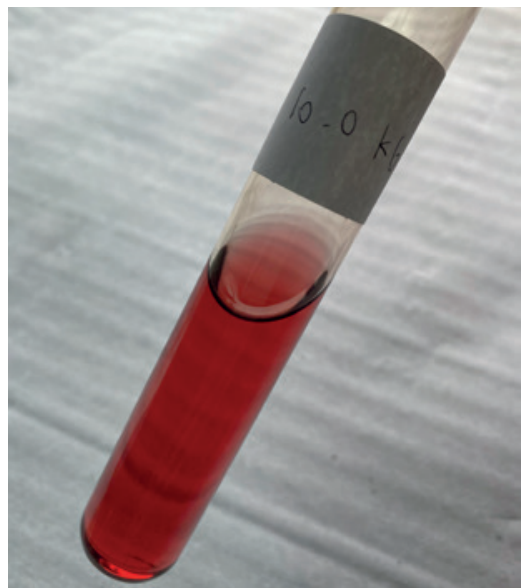

c)

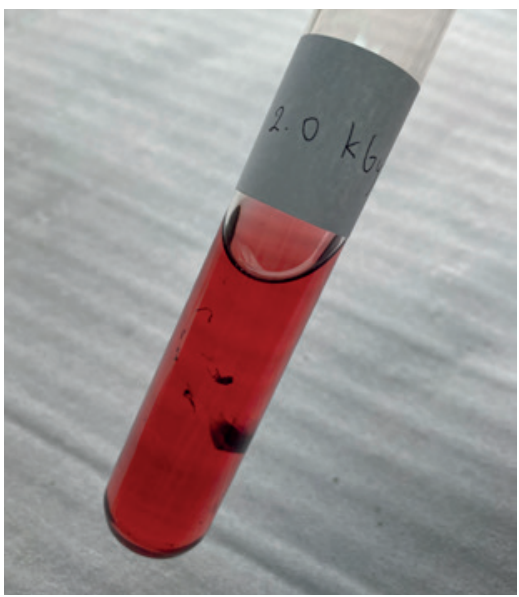

f)

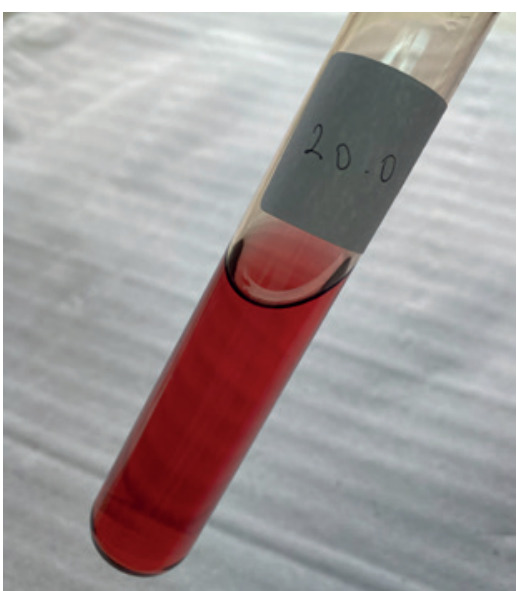

Fig. 5. PTFE-AuNP solution samples: non-irradiated (a) and irradiated with dose of b) 0.5 kGy (low aggregation), c) 2 kGy (high aggregation), d) 5 kGy, e) 10 kGy, f) 20 kGy 
acrylic acid)-grafted AuNP [P(HEMA-MAA)-AuNP] exhibited no aggregation under TEM analysis [14].

\section{CONCLUSION}

This study shows that the four-step mechanism of AuNP synthesis could be seen via naked eye by observing its color changing. The UV-Vis data obtained showed that the size of PTFE-AuNP particles produced was $20 \mathrm{~nm}$ with $520 \mathrm{~nm}$ absorption peak value. With absorbed dose of 0.5 and $2 \mathrm{kGy}$, long-term shelf life was lower compared to 5, 10 and $20 \mathrm{kGy}$ due to more visible aggregation within 30 days. Overall, the Turkevich method is one of simple methods to synthesize $20 \mathrm{~nm}$ AuNP and centrifugation provides quick and reliable washing of AuNP solution. Future research regarding mechanism of grafting polymer to AuNP surface would be explored.

\section{ACKNOWLEDGEMENT}

The authors would like to thank the Malaysia Ministry of Higher Education for the financial support through the granted Fundamental Research Grant Scheme (FRGS/1/2019/STG02/ UKM/02/6) funds and Nuclear Technology Research Centre, Faculty of Science and Technology, Universiti Kebangsaan Malaysia (UKM) for UV-Vis analysis.

\section{REFERENCES}

[1] Woźniak A., Malankowska A., Nowaczyk G. et al.: Journal of Materials Science: Materials in Medicine 2017, $28,92$. https://doi.org/10.1007/s10856-017-5902-y

[2] Guo J., Rahme K., He Y. et al.: International Journal of Nanomedicine 2017, 12, 6131. https://doi.org/10.2147/IJN.S140772

[3] Rostami A., Sazgarnia A.: Nanomedicine Journal 2019, 6, 147. https://doi.org/10.22038/NMJ.2019.06.00001

[4] Kang M.S., Lee S.Y., Kim K.S. et al.: Pharmaceutics 2020, 12, 701. https://doi.org/10.3390/pharmaceutics12080701

[5] Turkevich J., Stevenson P.C., Hillier J.: Discussions of the Faraday Society 1951, 11, 55. https://doi.org/10.1039/DF9511100055

[6] Brust M., Walker M., Bethell D. et al.: Journal of the Chemical Society, Chemical Communications 1994, 801. https://doi.org/10.1039/C39940000801

[7] Jana N.R., Gearheart L., Murphy C.J.: Langmuir 2001, $17,6782$.

https://doi.org/10.1021/la0104323
[8] Hu M., Chen J., Li Z.-Y. et al.: Chemical Society Reviews 2006, 35, 1084. https://doi.org/10.1039/B517615H

[9] Dong J., Carpinone P. L., Pyrgiotakis G. et al.: KONA Powder and Particle Journal 2020, 37, 224. https://doi.org/10.14356/kona.2020011

[10] Yang Y., Liao S., Luo Z. et al.: Nanoscale 2020, 12, 12007. https://doi.org/10.1039/C9NR09481D

[11] Nicol J.R., Dixon D., Coulter J.A.: Nanomedicine 2015, 10, 1315. https://doi.org/10.2217/nnm.14.219

[12] Pitkänen L., Striegel A.M.: TrAC Trends in Analytical Chemistry 2016, 80, 311. https://doi.org/10.1016/j.trac.2015.06.013

[13] Hanauer M., Pierrat S., Zins I. et al.: Nano letters 2007, 7, 2881. https://doi.org/10.1021/n1071615y

[14] Le Goas M., Paquet M., Paquirissamy A. et al.: International Journal of Nanomedicine 2019, 14, 7933. https://doi.org/10.2147/IJN.S211496

[15] Tsekov R., Georgiev P., Simeonova S. et al.: Comptes Rendus de L'Academie Bulgare des Sciences 2017, 70, 1237. https://arxiv.org/abs/1702.04513

[16] Kim H.-M., Jeong D.H., Lee H.-Y. et al.: Optics \& Laser Technology 2019, 114, 171. https://doi.org/10.1016/j.optlastec.2019.02.002

[17] Yadav J.: International Journal on Future Revolution in Computer Science \& Communication Engineering 2018, 4, 220.

http://www.ijfrcsce.org/index.php/ijfrcsce/article/ view/1502

[18] Balasubramanian S.K., Yang L., Yung L.-Y. L. et al.: Biomaterials 2010, 31, 9023.

https://doi.org/10.1016/j.biomaterials.2010.08.012

[19] Polte J., Ahner T.T., Delissen F. et al.: Journal of the American Chemical Society 2010, 132, 1296. https://doi.org/10.1021/ja906506j

[20] Pattadar D.K., Zamborini F.P.: Langmuir 2019, 35, 16416. https://doi.org/10.1021/acs.langmuir.9b02421

[21] Thanh N.T., Maclean N., Mahiddine S.: Chemical Reviews 2014, 114, 7610. https://doi.org/10.1021/cr400544s

[22] Li Y., Luo Q., Hu R. et al.: Chinese Chemical Letters 2018, 29, 1845. https://doi.org/10.1016/j.cclet.2018.11.016

[23] Xing Y., Han J., Wu X. et al.: Analyst 2020, 145, 7932. https://doi.org/10.1039/D0AN01019G

Received 20 IX 2021. 